Disrupted Lives 



\section{Disrupted Lives}

HOW PEOPLE CREATE MEANING

IN A GHAOTIC WORLD

GAY BECKER

UNIVERSITY OF CALIFORNIA PRESS

Berkeley Los Angeles London 
University of California Press

Berkeley and Los Angeles, California

University of California Press, Ltd.

London, England

First Paperback Printing 1999

(C) 1997 by

The Regents of the University of California

Library of Congress Cataloging-in-Publication Data

Becker, Gaylene.

Disrupted lives : how people create meaning in a chaotic world /

Gay Becker.

p. $\mathrm{cm}$.

Includes bibliographic references and index

ISBN 0-520-20913-3 (cloth : alk. paper). — ISBN 0-520-20914-I (pbk :

alk. paper)

1. Life change events-United States. 2. Adjustment

(Psychology)-United States. I. Title. BF637.L53B43 1998

$302.5-\mathrm{dc} 21$

$96-52482$

Printed in the United States of America

$\begin{array}{lllllllll}9 & 8 & 7 & 6 & 5 & 4 & 3 & 2 & 1\end{array}$

The paper used in this publication meets the minimum requirements of American National Standard for Information Sciences-Permanence of Paper for Printed Library Materials, ANSI 239.48-1984. $(0$ 
For my aunt, Hazel Perry,

and

in memory of my uncle, John Perry 
